\title{
The Visegrad Group as an Ambitious Actor of (Central-)European Foreign and Security Policy
}

\author{
LADISLAV CABADA AND ŠÁRKA WAISOVÁ
}

$\frac{\text { DE }}{\mathrm{G}} \stackrel{\text { DE GRUYTER }}{\text { OPEN }}$

Politics in Central Europe (ISSN: 1801-3422)

Vol. 14, No. 2

DOI: 10.2478/pce-2018-0006

\begin{abstract}
Even after achieving its goals, i.e. the entrance of member states into NATO and the EU, the Visegrad Group has managed to profile itself as a significant collective actor. Analyses to date clearly show that the group is able to function as a distinct and even key actor in various policies, including those within the EU; this statement is without doubt valid primarily for the region of the European neighborhood policy and the Eastern partnership, but also for enlargement policy and its clear targeting of the Western Balkans. We can also observe a highly proactive approach in issues linked to security, primarily in the energy sector and recently also cyber security. Nonetheless, all of these and many other significant V4 activities have been overshadowed of late by dispute between the group and a significant portion of members states on perspectives regarding the migration crisis including the tools to deal with it or preventive measures to prevent it from continuing or repeating. This stance on the issue, however, can be seen as proof of the relative power and success of the V4.
\end{abstract}

\section{Keywords: Visegrad Group; European Union; security policy}

Mainly from the perspective of Central European political science, the Visegrad Group is one of the most significant regional groupings functioning in contemporary Europe or the European Union. In addition to groups (past and present) such as the CEFTA initiative, the Three Seas Initiative, and to a certain degree European macro-regional strategy, which is strongly reflected in Central and Central-Eastern Europe (cf. Walsch 2015; Cabada - Walsch 2017), the V4 is the bearer of active policies and engages in a number of issues independently both within the EU and outside the Union's area and agenda. This impression is 
made stronger by the emphasized presentation of accomplished goals that were defined during the group's foundation in 1991, i.e. membership in the North Atlantic Alliance and full-fledged membership in the EU. This impression was also strengthened by a perception of the group as the leader of the countries of Central-Eastern Europe, whether these countries were EU members or still attempting to gain membership. Self-presentation of the V4 as a successful model that should be followed by other countries of Central-Eastern and Southeast Europe is one of the basic starting points of the V4 member states' foreign and development policy toward the region of the Western Balkans or the group of countries engaged in the Eastern Partnership (EaP) program.

In addition to building its position as a model and mediator of "Europeanization" and European policies toward the group of candidate countries of the Western Balkans, the Visegrad Group has attempted in the last decade to promote itself as an alternative or - neutrally speaking - an additional group of countries that introduces agenda within the EU and profiles itself as a significant collective actor. For instance, according to Czech political scientist Michal Kořan (2012: 208-209), after 2009 the V4 changed its rather defensive style and began to offer significantly more proactive stances "when it emphasized its ambition to become one of the needed and energizing factors in the project of European integration as its goal." In this context, Kořan points out that the V4 is characterized by three clearly declared goals that are incorporated into V4 policy: 1) the support of the Eastern and Southeastern direction of EU enlargement; 2) the support of the Eastern dimension of European neighborhood policy; and 3) a shared vision of regional energy policy. All three topics are reflected in the individual contributions brought together in this collective monograph, which deals with the security, foreign and European policy of the Visegrad Group and of its member states.

Nonetheless, at present we see and feel that these topics mentioned above have been clearly overshadowed after 2015 by a group-led resistance to mainstream EU policy in the issues of the so-called migration crisis (cf. Bauerová 2018a, Bauerová 2018b). The ambition to become an alternative "core" or motor for the EU was thus overshadowed by the image of a problematic group that is capable of powerfully and also relatively effectively destroying (in a temporary sense) the efforts for an EU-wide solution (i.e. a one-sided solution that was mostly forced by member states) to the wave of migration. From a medium-range perspective, however, such behavior has blocked the path to introducing agenda and dealing with other policies. The ambition to modify various European policies or promote its own priorities - of which energy policy has seemed in the past and present to be crucial, as well as policies concerning further EU enlargement and the EU's relationship toward Eastern neighbors located between the present EU and Russia - has thus been degraded. This includes the risk that rational V4 propositions will be refused due to the fact that they 
are being promoted by countries that are seen as problematic by the European mainstream. As Hungarian political scientist Boglárka Koller pointed out at a debate on Central European cooperation at the $23^{\text {rd }}$ annual conference of the Central European Political Science Association (CEPSA) in Wrocław (September 14-15, 2017), Western Europe sees the V4 as "laggards" while the countries of Central Europe see themselves as "pioneers".

As Olaf Wientzek claims (2017: 47), the V4's actions since 2015 show that regional cooperation can act as a motor but also a brake on European integration. It becomes a brake "when it becomes a cartel that acts against the interests of the EU and thus causes serious damage to the European integration process as such; the French-German disregard for the Stability and Growth Pact is one such example." Wientzek (2017: 48) goes on to claim that at present the V4 is viewed through the prism of its own stance on issues of the migration crisis primarily as a "negative coalition". This is a generalizing and distorted view, but nonetheless one that follows the significant fact that the V4 is perceived on a European level as a "purely defensive project". Thus, the ambition declared at the end of the first decade of the $21^{\text {st }}$ century is overshadowed. In this sense, Wientzek calls for a certain type of "restart" by appealing to the V4 to introduce and promote a "positive agenda" on a European level.

Radko Hokovský (2017: 53) is of a similar opinion in his argument that, due to strongly different approaches and economic rivalry, "the Visegrad Group has not yet played a highly significant or visible role throughout the course of most of its existence. This has changed with the migration crisis in 2015." At the same time, the author correctly points to the fact that the request on the part of V4 leaders to stop illegal migration formulated in 2015 in opposition to the mainstream later became the general message of the majority of politicians in EU countries in 2017. He is referring to the fact that the leaders of the majority of EU countries eventually took the position held by V4 politicians but have not yet erased the "negative, almost toxic image (...) that was at least partially caused by poor political communication and unsuitable rhetoric on the part of V4 leaders. Strong critical statements and refusals, which were unaccompanied by constructive suggestions, did not help Western politicians in understanding or appreciating the stances of the Visegrad. Aside from the restrictive approach to migration, the $\mathrm{V} 4$ became infamous for its controversial constitutional steps taken by governments in Budapest and Warsaw. These non-liberal tendencies have only strengthened the image of the Visegrad as a backwards group of post-communist countries that are unable to integrate into a modern and multiculturally conceived Europe" (Hokovský 2017: 54). In Hokovský's words, the V4 is in a situation that is clearly dominated by the Germany-France duo and generally by the "Western" portion of the EU and is condemned to the role of the brake. This, however, can be a brake that can be destructive and subversive on one hand and a "healthy and constructive regulation" on the other. 
To summarize, both skeptics and optimists (the latter perhaps more so) see the V4 as a stabilized regional cooperative structure that will at least formally function into the future and that at present can relatively assertively function as an integrator of broader Central and Eastern European - or even "Union-wide" alternatives to the motor of the EU, which is represented by the Germany-France duo and their primary partners (Benelux or other countries or groups of countries including some of Central-Eastern Europe, namely Slovenia and Estonia). In our minds, it would be worthy to ask what alternatives the V4 offers in individual policies or to what degree the group itself is capable of defining its shared interests, priorities, and goals and promoting them not only in the framework of Central Europe, but also on an EU or Europe-wide level.

The collection of papers that we have put together in this special issue focuses primarily on wholly current issues while suppressing the historical dimension. We are fully aware of the fact that, aside from the evident advantages, such an approach also carries numerous risks in terms of limitations on contextualization. Nonetheless, we claim on a general level that the nostalgically formulated ideas of Central Europe after the fall of the Iron Curtain have clashed with reality in the form of preferences of national interests before a shared Central European identity. Not only V4 countries, but fundamentally all post-communist countries of Central-Eastern Europe in the period of transition and "catching-up" to the West have accepted a dominant and basically single narrative, that is joining (Western-)European integration structures, i.e. NATO and the European Communities (EC) or the EU. Individual countries naturally swayed between various strategies of "catching up" - rivalry vs. cooperation (or independent vs. coordinated activity); looking for a new relationship toward countries of Central-Western Europe (Germany, Austria, or Italy) and other EU members; searching for new positions toward Russia or Eastern/Southeast Europe; balancing between an exclusively pro-Western position (including the risk of Central Europe "disappearing" after its entrance into NATO and the EU) and the multi-vector foreign policy with a specific emphasis on Russia, and so on. Entrance into NATO in 1999 (with the exception of Slovakia, which joined the Alliance in 2004) and the EU in 2004 ended this phase (Cabada - Walsch 2017: 15-17). In the Kroměřiž Declaration of May 2004, the Visegrad Group declared it would further exist despite achieving its primary goals, introducing newly declared ones - enlargement to the Western Balkans, the eastern vector of EU policy, and the issue of energy security. The first five years after the entrance of its member states into the EU, the $\mathrm{V} 4$ gave the impression of an exhausted community that would fulfill optimistic forecasts (pro-Westernization) or skeptical predictions (becoming geopolitically absorbed) on the dissolution or disappearance of the Central European region.

However, since the end of the first decade of the $21^{\text {st }}$ century, we can observe a fundamental turnaround in this development, which was linked (among other 
factors) to Central Europe's new profiling headed by the Visegrad Group. So-called Central-Eastern Europe, i.e. the group of post-communist EU-countries, began to be perceived as a structure challenging various fundamental norms or customs of the historical EU-15. At the same time, the Visegrad Group was and is (wholly justifiably in regard to its own self-projection in Central-Eastern Europe) perceived as a leader of this "second" or "other" Europe. Gradually, however, the group found itself in isolation, as other countries of the region observed this linear trajectory; this separation is most significant in the case of Slovenia, which is (justifiably) considered to be the most Euro-optimistic country within the historical EU-15 (cf. Cabada - Hlaváčková 2016 or Cabada Waisová 2010), but also that of the Baltic states, which in 2011 (Estonia), 2014 (Latvia), and 2015 (Lithuania) entered the Eurozone. As we have noted above, this isolation or at least peripherization was intensified by the so-called refugee crisis or the debate linked to the idea of the redistribution of migrants within the EU after 2015. In this situation, the Visegrad Group closed its doors and to external observers became an "unholy alliance" or "the big, bad Visegrad", which had gone off on an "unsettling new direction" (Economist, 28. January 2016).

This closing-up on the part of the Visegrad Four and its leaders on the issue of the migration crisis cannot however cover up the fact that there are many dissonances among member states linked both to history (e.g. Slovak-Hungarian relations or the issue of the Hungarian minority's position in Slovakia) and the present (the relationship with Russia is only one of the examples of the fundamental divisions between V4 countries). The V4 continues to maintain an informal character of cooperation that is founded on the principle that such cooperation is developed only in issues in which relatively simple agreement can be assumed. Several contributions in this book also point to the same fact - for instance, in terms of security we see agreement primarily in areas of so-called "soft security" (Waisová 2018), while in terms of "hard security" a gap between Poland and other member states is widening (Ušiak 2018a; Ušiak 2018b; cf. Cabada - Walsch 2017:135). Many authors in this context point to the fact that Poland is otherwise determined through the prism of hard power and/or hard security both in regard to foreign policy ambitions and regional perspectives. For example, Drulák and Šabič's $(2012,312)$ analysis of international policy issues linked to Central Europe, in which they include other countries (Slovenia, Austria, Romania, Germany) along with the V4, claims that: "Four small (Central European - author's note) countries (Czech Republic, Hungary, Slovakia, and Slovenia - author's note) are linked to the Danube Region, while Poland is linked to the Baltic Region. These differences lead to dissimilarity in the perception of regional foreign policy interests. Poland is active in Belarus and Ukraine, countries which are remote to Slovenia. On the contrary, Poland and other V4 countries and Austria are much less engaged in Balkan affairs". Stances on Russia among V4 states also differ, as the situation has become more intense after 
the Russian occupation of Crimea and in general after Russia's involvement in the internal development of Ukrainian policy. "Contrary to Poland, the other three V4 countries have not been strongly active in formulating an EU position toward Russia. Furthermore, the top representatives of these countries have occasionally made statements that have cast doubt on their unified European position" (Kucharczyk - Mesežnikov 2015: 11).

Poland's specific position not only within the V4 but also in regard to the broader Central-Eastern European region and the Europe-wide dimension of politics is reflected upon in a significant portion of the contributions in this book. Thus we see Poland's differing positions and ambitions in the area of security and energy (which is clearly linked to security), and also in efforts to introduce its own agenda on a European level and to form regional alliances or alternative formats of Central European cooperation according to the country's own notions. In this regard, the other three member states are wholly different, as they have no material or ideological grounds on which to build the theoretical ambition of becoming a regional power. Nonetheless, this fact has not kept these countries from making their own efforts to take position as leader of the group - Czech Republic, Hungary - or on the contrary to take the position of dissident, primarily in regard to the pragmatic search for a position on a European level. In this regard, we should mention the unanimous declaration of Slovakia's leading representatives from the period approximately covering the course of the past year. Before elections to the Chamber of Deputies of the Czech Parliament in October 2017, i.e. before knowing what political parties Czech voters preferred, Slovak Prime Minister Fico made it clear that his country did not intend to risk shifting outside of the now forming or potential core of the European union because of Visegrad or broader Central European cooperation. At the same time, he clearly pointed out that a sacrifice for the future position of Slovakia at the core of the EU may even be giving up Visegrad cooperation itself: "For Slovakia, the Visegrad Four does not represent an alternative to the EU. The V4 is not the living space that we imagine for our future. Our living space is in the EU" (Fico pospíchá do jádra EU 2017). Fico showed an even more decided and highly pragmatic stance after the parliamentary elections in the Czech Republic in October 2017, which ended in success for protest parties with a reserved or directly negative stance on European integration and showed that the hopes for a re-liberalization and re-Europeanization of the V4 with the use of the Slavkov Declaration would not materialize. Fico met with Slovak President Andrej Kiska and Chairman of the National Council Andrej Danko two days after Czech parliamentary elections and, in a mutual communiqué, declared the pro-European and pro-Western direction of Slovakia in relation to the EU and NATO. Fico subsequently presented this communiqué to the press with the metaphor of an "island", i.e. "a pro-European island in Central Europe” (Slovensko je proeurópsky ostrov 2017). This blow to all three V4 
partner countries resonated in an especially critical manner in connection to previous uses of the island metaphor in Central Europe, for instance E. Beneš and Czechoslovak politicians' declaration of interwar Czechoslovakia as an island of democracy. A similar sign of distance is without a doubt the regional Slavkov Triangle activity launched in 2015 by Austrian, Czech, and Slovak diplomacy at the beginning of 2015. This declaration was evidently meant to function as an option for leaving the V4 in the event that, due to the procedures of the Hungarian and Polish governments and namely due to the anti-liberal steps of Hungary's Prime Minister Viktor Orbán and the informal leader of Polish politics Jarosław Kaczyński, the group as a whole becomes unpalatable to the other countries of the EU. This unpalatable nature was largely strengthened by the steps taken by both aforementioned governments in diverting their political systems from the principles of a liberal rule of law and the reaction of the European Union against Poland by launching proceedings against it under Article 7 of the Treaty of the European Union. Disruption of the principle of the rule of law could in this case lead to the suspension of the country's voting rights at the Council of the EU's negotiations (cf. e.g. Ehl 2017). Nonetheless, the results of elections in the Czech Republic and Austria in 2017 and mainly the subsequent steps of the key actors of both countries show that the group meant to function as a "lifeline" for Hungary in the case that it decided to pragmatically take the Polish route of "confrontation" (cf. Palata 2015) is presently in a state of "clinical death". At the same time, however, this situation caused a reversal in Polish foreign-policy and regional activity in the Three Seas Initiative, efforts to revitalize the Weimar Triangle, or independent activities from the position of regional power in Central-Eastern Europe (Cabada 2018).

Within the V4 and its foreign policies, just as in the area of directly constructing a relationship with the EU, its institutions, and other member countries, we can observe a whole score of discrepancies that cast doubt on the oft-used label of a unified group that is often (negatively) attributed to the Visegrad by the "rest" of the EU or Western Europe and a label that politicians of V4 countries at times even boast of, primarily in efforts to demonstrate to their domestic audience their alleged determination to defend national interests against "Brussels". Analyses focusing on energy policy and primarily energy security point to similar differences. Here "cooperation within the Visegrad Group has gained a stronger charge through repeated energy crises that Europe, primarily Central-Eastern Europe, has felt in connection to relations between Ukraine and Russia and similarly in connection to climate plans adopted within NATO" (Walsch 2015: 137); nonetheless, steps taken by Hungary and the behavior of other V4 countries points to the strongly national undertones of negotiation. On one hand we see the wager of Polish diplomacy on imported liquefied natural gas to flow through Central-Eastern Europe in a north-south direction from the terminal in Świnoujście to the Croatian terminal on the island of Krk, a matter 
that the construction of the Three Seas Initiative is closely linked to (Cabada 2018). On the other hand, we see efforts of other V4 countries to preserve and strengthen the share of nuclear energy in the overall mix. It was the decision to build two new blocks of the nuclear power plant in Paks, Hungary in 2014 meant to be completed by Russian company Rosatom and financed by a Russian loan - that disrupted the plans for a unified approach on the part of Central Europe in the field of energy security and resource diversification. Thus the V4 cannot be labeled a coherent group in the field of energy security either. Thus, in addition to topics of migration or the protection of the EU's external borders, the analyses presented in this special issue point to the further enlargement of the EU, primarily the countries of the Western Balkans, as the most distinct shared agenda on which V4 states agree. Here, in the cases of Hungary, Czech Republic, and Slovakia, we see clear and long-term agreement. Even Poland in this respect is not in principle disagreement, although its agenda is dominantly focused on the issue of Ukraine. Poland in is no way challenging the need for the EU to enlarge into the countries of the Western Balkans, and is merely devoting its energy to another vector, i.e. the region that neighbors the EU in its present form.

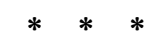

This special issue has been divided into two sections, the first of which primarily deals with the issue of security and cooperation. The second deals with the foreign or European policy of the V4. These dimensions cannot naturally be fully divided, and therefore this division is in fact more of a technical nature and both sections create a relatively homogeneous whole.

In the first section, which focuses on the security aspects of cooperation, we drew from the fact that the current role of the state in the field of security does not only include preserving state sovereignty, territorial integrity, or the security of the population, but also a wide spectrum of non-military aspects that are impacting states more and more significantly. In the past, security and national defense depended on its army and power, while today we can observe and study a state's security from a score of different perspectives. This section of the book is focused on security and defense cooperation of V4 countries, which is not generally a priority for politicians and journalists in a time of peace but becomes an issue of a state's survival in cases of acute security threats. The changes that have taken place in the last roughly three decades in the field of security reveal the basic developmental trends in security policy such as the shift from hard security to soft security, the strengthening of non-military aspects of security, the growth in the number of actors in the global political system, strengthening of states' integration tendencies in the sense of collective and cooperative security, various state approaches (interests) proclaimed in their foreign-security doctrines, 
or various implementations of strategies and security policies over the course of this period. In this section, through analytical means, we attempt to define and compare the primary starting points and possibilities for cooperation in the field of security between states of the Visegrad Group - the Czech Republic, Slovakia, Poland, and Hungary. For all four countries, we define the security environment with a special emphasis on forms of $\mathrm{V} 4$ cooperation in this area. Finally, we focus on key non-military threats or dimensions of security policy environmental problems and cyber security, which impact all V4 member states.

In addition to the four mentioned analyses, we have decided to add one more, which is focused on the issue of the migration policy of V4 countries and the group as a whole in connection to the migration crisis of the summer of 2015 and the following period. At the same time, this text forms a sort of natural bridge to the second section of this special issue, which focuses on European or V4 foreign policy and the foreign policy of its member states. In terms of the development of the V4 and its relations with the EU as a political institution represented by central institutions - primarily the European Commission, European Parliament, and the Council of EU - the migration crisis represents a certain dividing line stemming from the construction of the image of the V4 as a disruptor of "harmony" and long-existing mechanisms of consensus within the European integration process. V4 countries have evidently handled the crisis as a security issue; they have strongly securitized the topic of migration and many political actors within the $\mathrm{V} 4$ have built their political strategy primarily on a policy of fear linked to the demonization of migration and primarily Islam as an aggressive, non-liberal, and non-European religious-political system with which they link all arriving refugees of war and other types of migrants from northern Africa or the Middle East.

The second section of this special issue carries on from the first in an article reflecting the position of the V4 within the EU. This position is naturally determined by other topics than migration alone. The enlargement policy is a distinct European policy for V4 countries and is dealt with in the following text with regard to the region of the Western Balkans. This analysis is accompanied by an article devoted to reflection on the position of Visegrad cooperation in terms of new institutional and content offers of cooperation in Central and Central-Eastern Europe. Last but not least we present the article focusing on the issue of the possible replication of the division of Europe, i.e. the construction of a certain mental or construed barrier between old (Western) and new (Eastern) Europe. Though such a division may seem banal from a scientific standpoint, it can function all the better in the area of practical and populist-motivated policy in both of these hypothetical parts of the Union.

The effort of this special issue is, among other factors, to provide a sufficient number of arguments against the trivialization of politics and labeling based on a score of prejudices, use of double standards, and disregard for the multi- 
-paradigmatic and multi-dimensional nature of these issues and problems. We find it absurd in terms of a construed division of Europe/the EU into Western and Eastern sections (Walsch 2018) for a strongly pro-European Slovenia or Estonia to be "lumped" into the category of "problematic Eastern Europeans" while, for instance, Italy and its exceptionally problematic economy and now also political situation is wholly ignored in the interest of preserving the appearance of a "properly functioning Western Europe". Therefore we have attempted to create a comprehensive portrayal of selected policies of the V4 (and aspects of them) as a whole and of their member states. We have also analytically pointed to how synergetic the V4 states' foreign, security, and European policy is or how convergent it is within the group on an EU level and where we observe deviations and more systematic divergences that may point to a fundamental rift within the EU or the V4 itself.

\section{References}

Bauerová, H. (2018a): Migration policy of the V4 in the context of migration crises. Politics in Central Europe 14 (2). Doi: 10.2478/pce-2018-0011.

Bauerová, H. (2018b): The V4 and European Integration. Politics in Central Europe 14 (2). Doi: 10.2478/pce-2018-0012.

Big, Bad Visegrad (2016): Economist, 28 January 2016, available at https://www.economist.com/ news/europe/21689629-migration-crisis-has-given-unsettling-new-direction-old-alliance-big-bad-visegrad (11 September 2017).

Cabada, L. (2018): Visegrad Cooperation in the Context of Other Central European Cooperation Formats. Politics in Central Europe 14 (2). Doi: 10.2478/pce-2018-0014.

Cabada, L. - Hlaváčková, H. (2016): Zahraniční politika Slovinska. Praha: Libri a MUP Press.

Cabada, L. - Waisová, Š. (2010): Slovenia as an EU-member: a Euroenthusiastic society and political elite. In: Drulák, P. - Šabič, Z. (eds.), The Czech and EU Presidencies in a Comparative Perspective. Dordrecht: Republic of Letters Publishing BV, 37-54.

Cabada, L. - Walsch, Ch. (2017): Od dunajské federace k Visegrádu... a zpět? Tradiční a nové formáty středoevropské spolupráce. Prague: Libri.

Drulák, P. - Šabič, Z. (2012): Conclusions: Institutions, Geography and Uncertainty. In: Šabič, Z. - Drulák, P. (eds.), Regional and International Relations of Central Europe. Houndmills: Palgrave Macmillan, 310-316.

Ehl, M. (2017): Eurokomisaři hrozí Polsku odebráním hlasovacích práv v unii kvůli porušování zásad právního státu. Mad'arsko chce řizení vetovat. Hospodářské noviny 20. 12. 2017, available at https://zahranicni.ihned.cz/c1-65997470-evropska-komise-tresta-polsko-za-porusovani-pravniho-statu (8 June 2018). 
Hokovský, R. (2017): Role Visegrádská skupiny v EU - pohled zevnitř. In Tungul, L. (ed.), Pravicová řešení politických výzev pro rok 2018, Praha, Wilfried Mertens Centre for European Studies, Konrad-Adenauer-Stiftung a TOPAZ, 51-55.

Fico pospíchá do jádra Evropské unie (2017). Dnes, 14. 9. 2017, available at https://www.novinky. cz/zahranicni/evropa/449147-fico-pospicha-do-jadra-evropske-unie.html (14 September 2017).

Kořan, M. (2012): The Visegrad Group on the Threshold of Its Third Decade: A Central European Hub? In Drulák, P. - Šabič, Z. (eds.), Regional and International Relations of Central Europe, New York, Palgrave Macmillan, 201-217.

Kucharczyk, J. - Mesežnikov, G. (2015a): The Visegrad countries have a stake in the success of a pro-European Ukraine. In: Kucharczyk, J. - Mesežnikov, G. (eds.), Diverging Voices, Converging Policies: The Visegrad States' Reactions to the Russia-Ukraine Conflict. Varšava: Heinrich Böll Stiftung, 9-12.

Palata, L. (2015): Slavkov, bermudský trojúhelník české diplomacie. Zahraničná politika 20. 2. 2015, available at https://zahranicnapolitika.sk/slavkov-bermudsky-trojuhelnik-ceske-diplomacie/ (8 June 2018).

Slovensko je proeurópsky ostrov, hovorí Fico po vol'bách v Česku a spojil sa s Kiskom a Dankom (2017). Denník. 23. 10. 2017, available at https://dennikn.sk/919225/slovensko-je-proeuropsky-ostrov-hovori-fico-po-volbach-v-cesku-a-spojil-sa-s-kiskom-a-dankom/ (26 October 2017).

Ušiak, J. (2018a): Security Environment of V4 Countries. Politics in Central Europe 14 (2). Doi: 10.2478/pce-2018-0008.

Ušiak, J. (2018b): V4 Security Cooperation. Politics in Central Europe 14 (2). Doi: 10.2478/pce2018-0007.

Waisová, Š. (2018): The Environmental Situation in the Visegrad Region: Neglect and Insufficient Cooperation in the Face of Serious Environmental Threats. Politics in Central Europe 14 (2). Doi: 10.2478/pce-2018-0009

Walsch, Ch. (2015): Aufbruch nach Europa. Sieben Beiträge zur europäischen Integration Ungarns seit 1990. Herne: Gabrielle Schäfer Verlag.

Walsch, Ch. (2018): An east-west divide in the European Union? The Visegrad Four states in search of the historical self in national discourses on European intergration. Politics in Central Europe 14 (2). Doi: 10.2478/pce-2018-0015.

Wientzek, O. (2017): Visegrádská spolupráce - motor nebo brzda evropského integračního projektu. In Tungul, L. (ed.), Pravicová řešení politických výzev pro rok 2018, Praha, Wilfried Mertens Centre for European Studies, Konrad-Adenauer-Stiftung a TOPAZ, 45-50.

Ladislav Cabada studied Political Science at the Charles University in Prague/ Czech Republic; during his doctoral studies he spent one academic year at the University of Ljubljana/Slovenia. He works as Associate Professor and guarantee of study programmes Political science (M.A. and PhD. level) at the Department of Political Science and Humanities, Metropolitan University Prague/Czech Republic; he is also permament Visiting Scholar at the National University of Public Service in Budapest/Hungary. In his research he specializes on comparative politics of East- 
-Central Europe, above all the party systems and political actors, and the analysis of selected East-Central European countries policies, and regional studies of Central and South-Eastern Europe. He is author or co-author of more than one hunderd scholar publications. Among the most recent we can mention books Od dunajské federace k Visegrádu... a zpět? Staré a novéformáty středoevropské spolupráce [From the Danubian Federation towards the Visegrad... and back? Old and new formats of Central European cooperation] (with Christopher Walsch, 2017), Balkánské komunismy [Balkan Communisms] (with Markéta Kolarčíková, 2016), Zahraniční politika Slovinska [Slovenian Foregin Policy] (with Hana Hlaváčková, 2016), Současná komparativí politologie: Klíčové koncepty [Contemporary comparative politics: key concepts] (with Jakub Charvát and Ondřej Stulík, 2015) or Political Parties in East Central Europe (with Vit Hloušek and Petr Jurek, 2014).

E-mail: ladislav.cabada@mup.cz

Šárka Waisová studied International Relations and International Territorial Studies at the Charles University in Prague/Czech Republic, Phillips-Universität in Marburg and Technical University of Dresden/Germany. She holds the PhD in Political Science and European Studies from the Palacky University in Olomouc/Czech Republic and habilitation (associate professor degree) in Political Science with the focus on Security studies from the Masaryk University in Brno/Czech Republic. She works as Associate Professor and guarantee of study programmes International Relations (M.A. and PhD. level) at the Department of Political Science and International Relations, University of West Bohemia in Pilsen/Czech Republic. In 2016-2018 she was an International Chair at the National University of Public Service in Budapest/Hungary, she realised also longer research stays in Taiwan, U.S. and Canada. In her research she is concerned with foreign policy, security, conflict resolution and knowledge diffusion. She is author or co-author of about one hundred scholar publications. Among the most recent we can mention books Environmental cooperation as a tool for conflict transformation and resolution (Lexington Books, 2017) or The role of Taiwanese civil society organizations in Cross-Strait relations (Routledge, 2018).

E-mail: sarka.waisova@mup.cz and waisova@kap.zcu.cz 